\title{
TRUNK MOBILITY AFTER MINIMALLY INVASIVE ONE-LEVEL LUMBAR INSTRUMENTATION
}

\author{
MOBILIDADE DO TRONCO APÓS INSTRUMENTAÇÃO LOMBAR MINIMAMENTE INVASIVA EM \\ UM UUNICO NIVEL
}

\section{MOVILIDAD DEL TRONCO DESPUÉS DE LA INSTRUMENTACIÓN LUMBAR MÍNIMAMENTE INVASIVA EN UN ÚNICO NIVEL}

\author{
Marcelo Simoni Simões ${ }^{1}$, Ernani Vianna de Abreu ${ }^{1}$, Marcia Balle Kaiper ${ }^{1}$, Alessandro Machado da Silva², Thiane Alexandrino ${ }^{1}$ \\ 1. Hospital Mãe de Deus, Porto Alegre, RS, Brazil \\ 2. Ernesto Dornelles Hospital, Porto Alegre, RS, Brazil
}

\begin{abstract}
Objective: To evaluate the impact of a minimally invasive lumbar one-level fixation on trunk mobility and quality of life compared with the preoperative condition in 26 consecutive patients. Methods: The following data were collected preoperatively and postoperatively for the statistical analysis: maximal trunk extension and flexion angles, Visual Analog Scale of pain and Oswestry Disability Index scores. Results: There was improvement in all variables. Statistical significance was observed in trunk extension, pain, and Oswestry Disability Index. Although mobility in trunk flexion was higher in average values after surgery, this difference was not statistically demonstrated. Conclusion: Minimally invasive one-level lumbar fixation does not cause reduction of trunk flexibility in comparison to the mobility before surgery.
\end{abstract}

Keywords: Surgical procedures, minimally invasive/methods; Low back pain; Treatment outcome; Range of motion, articular; Spinal fusion.

\section{RESUMO}

Objetivo: Avaliar o impacto da fixação minimamente invasiva de um único nível lombar sobre a mobilidade do tronco e a qualidade de vida em comparação com o estado pré-operatório em 26 pacientes consecutivos. Métodos: Foram coletados os seguintes dados pré e pós-operatórios para a análise estatística: ângulos de flexão e extensão máxima do tronco, escore da Escala Visual Analógica para dor e do Índice de Incapacidade de Oswestry. Resultado: Houve melhora em todas as variáveis. Foi observada significância estatística para extensão do tronco, dor e Índice de Incapacidade de Oswestry. Apesar da mobilidade em flexão do tronco ter sido maior em valores médios no pós-operatório, essa diferença não foi estatisticamente demonstrada. Conclusão: A fixação lombar minimamente invasiva de um único nível lombar não causa redução na flexibilidade do tronco em comparação com a mobilidade antes da cirurgia.

Descritores: Procedimentos cirúrgicos minimamente invasivos/métodos; Dor lombar; Resultado do tratamento; Amplitude de movimento articular; Fusão vertebral.

\section{RESUMEN}

Objetivo: Evaluar el impacto de la fijación mínimamente invasiva en uno solo nivel lumbar en la movilidad del tronco y la calidad de vida en comparación con el estado preoperatorio en 26 pacientes consecutivos. Métodos: Se colectaron los siguientes datos pre y postoperatorios para el análisis estadístico: ángulos máximos de la flexión y extensión del tronco, la puntuación en la Escala Visual Analógica para el dolor e Índice de Discapacidad de Oswestry. Resultados: Hubo una mejora en todas las variables. Se observó significación estadística para la extensión del tronco, el dolor y el Índice de Discapacidad de Oswestry. A pesar de la movilidad en la flexión del tronco haber sido mayor en los valores medios en el postoperatorio, esta diferencia no fue demostrada estadísticamente. Conclusiones: La fijación lumbar mínimamente invasiva de un solo nivel lumbar no causa reducción en la flexibilidad del tronco en comparación con la movilidad antes de la cirugía.

Descriptores: Procedimientos quirúrgicos mínimamente invasivos/métodos; Dolor de la región lumbar; Resultado del tratamiento; Rango del movimiento articular; Fusión vertebral.

\section{INTRODUCTION}

A frequent question for the spine surgeon when indicating a lumbar fusion is the amount of movement restriction that will be imposed by the fixation, and how much this will impact on the patient's quality of life. Although most of the doctors' attention is focused on neurological status and pain control, the patient's concerns include the degree of limitation that the treatment could cause. There are several papers on spine mobility after fixation, the effects on adjacent levels, lesion of the back muscles, and the impacts on quality of life. In vitro and virtual experiments can measure the impact of some isolated factors on spine mobility, but this information does not necessarily reflect the clinical significance and the impact on activities of daily living. Although the biomechanical manifestation of disc degeneration is segmental hypermobility with widening of the neutral zone ${ }^{1,2}$ the clinical complaint is usually limitation of movement, with consequent pain or neuromuscular stabilization mechanisms. In this context, a study was conducted to evaluate trunk mobility before and after one-segment minimally invasive lumbar fixation, and its relationship with pain and functional performance, using physical evaluation instruments and validated clinical outcome scales. 


\section{METHODS}

A prospective longitudinal observational study was conducted on a series of 26 consecutive patients who underwent one-segment minimally invasive lumbar spine fixation.

The sample was composed of patients who sought the services of a private practice specialized in spinal surgery, between February 2011 and January 2013. The surgical technique in all cases was Transforaminal Lumbar Interbody Fusion (TLIF) associated with bilateral pedicle screw fixation, through a minimally invasive transmuscular approach, as described in a previous paper. ${ }^{3,4}$ Treatment was indicated and conducted by the two main authors. Inclusion criteria were degenerative disease in a single lumbosacral segment, associated with low back pain, with or without associated radicular symptoms, not responsive to at least tree months of conservative treatment, and availability of the patient to attend the follow-up visits. Subjects with a history of previous spine surgery, any major anatomical anomaly, hip problems, or other pathology that could interfere with the data collection were excluded from the study. There were no comparisons between different interventions or groups. The ethical principles highlighted by the Helsinki declaration were strictly observed, and all the participants were asked to sign an informed consent form.

Patients were evaluated for pain, disability and trunk mobility, preoperatively and 4 months after surgery. In the interval between surgery and reevaluation, patients were referred for physical therapy with back strengthening and muscle stretching of the lower limbs, avoiding trunk mobility exercises. The physical therapy was not standardized, and was performed in different clinics, according to availability and the preferences of the individual patients. Pain evaluation was performed with the Visual Analog Scale (VAS), and the degree of disability was determined using the Oswestry Disability Index Questionnaire (ODI) - validated version in Portuguese. Trunk mobility in flexion and extension was measured in degrees, with a Sanny ${ }^{\mathrm{TM}}$ fleximeter (American Medical do Brasil Ltda. São Bernardo do Campo, São Paulo/Brazil). The measurements were taken according to the technique described by the manufacturer, by only one physical therapist not involved with the patient's care.

The data were analyzed using the software IBM SPSS Statistics $21.0^{\mathrm{Tm}}$. The preoperative and postoperative mean values of VAS, ODI and trunk flexibility were compared by the Student's $t$ test. The null hypothesis is that trunk mobility is the same before and after surgery, and the alternative hypothesis is that they are different. A confidence interval of $95 \%$ was adopted.

\section{RESULTS}

A total of 26 patients were evaluated: 20 (77\%) males and 6 (23\%) females. The mean age was 41.6 years (range 18 to 58 years). The fused segment was L4-L5 in 13 patients (50\%) and L5-S1 in the other $13(50 \%)$. The mean time interval between the initial evaluation and surgery was 18 days (minimum of 0 and maximum of 84 days). The mean interval between surgery and postoperative evaluation was 123 days (minimum of 71 and maximum of 223 days). The mean values for pre- and postoperative VAS were 4.2 and 1.3, respectively. The mean values for ODI were 43.5 on pre and 26.1 in the postoperative evaluations. The differences were statistically significant $(p<0.05)$. The mean value for trunk extension before surgery was 20.1 degrees, increasing to 23.8 degrees after surgery. Although small, the difference of 3.7 degrees was statistically significant $(p=0.01)$. The mean value for trunk flexion before surgery was 52.5 degrees, increasing to 58.6 degrees after surgery. The difference of 6.1 degrees was not statistically significant $(p=0.138)$. The data are summarized in Table 1.

\section{DISCUSSION}

Questions about the consequences of spine fixation have been present since the popularization of the technique in recent decades. The impact of loss of a mobile segment on the patient's functional capabilities, and the biomechanical repercussions on the adjacent spinal segments is a field of extensive discussion, and alternative
Table 1. Collected data before and after single level lumbar spinal arthrodesis

\begin{tabular}{|c|c|c|c|c|}
\hline & Before & After & \multirow[b]{2}{*}{$\begin{array}{c}\text { Mean } \\
\text { Difference }\end{array}$} & \multirow[b]{2}{*}{$\begin{array}{c}\text { Confidence } \\
\text { Interval } \\
(p<0.05)\end{array}$} \\
\hline & $\begin{array}{c}\text { Mean } \\
\text { (Std. Deviation) }\end{array}$ & $\begin{array}{c}\text { Mean } \\
\text { (Std. } \\
\text { Deviation) }\end{array}$ & & \\
\hline VAS & $4.173(2.7493)$ & $1.342(2.1358)$ & -2.8308 & 0.00018 \\
\hline ODI & $43.462(14.8761)$ & 26.154 (16.198) & -17.3077 & 0.00036 \\
\hline $\begin{array}{c}\text { Trunk } \\
\text { extension }\end{array}$ & $20.115^{\circ}(9.4205)$ & $\begin{array}{l}23.808^{\circ} \\
(8.6349) \\
\end{array}$ & $+3.6923^{\circ}$ & 0.00997 \\
\hline $\begin{array}{c}\text { Trunk } \\
\text { Flexion }\end{array}$ & $52.5^{\circ}(16.931)$ & $\begin{array}{l}58.654^{\circ} \\
(18.631)\end{array}$ & $+6.1538^{\circ}$ & 0.13757 \\
\hline
\end{tabular}

techniques to avoid fusion have been proposed, aimed at reducing the damage imposed by this surgery. In cases of hip and knee surgery, there is no doubt as to importance of retaining or restoring the mobility of the joint, and no question as to the huge progress represented by the advent of reliable arthroplasty techniques. It is tempting to apply the same principles to the spine; however, the behavior of the functional spinal unit is fundamentally different from that of the other joints, and the question of functional impairment due to the loss of a single mobile segment has not yet been scientifically resolved. ${ }^{5}$ Moreover, in cases of low back pain, the association between loss of trunk mobility and quality of life do not seem to hold true. The patient's degree of disability seems to be more closely related to pain and neurological deficit than to trunk mobility. ${ }^{6}$ The results show that with good indication criteria and appropriate surgical techniques, one-level minimally invasive lumbar fixation can bring statistically significant benefits in terms of reducing the pain and disability, within a few months after surgery, as evaluated by VAS and ODI. Concerning trunk mobility, fixation of a single segment increased the global range of movement in flexion and extension, with a statistically significant value for extension. Segmental instability, loss of disc height, facet overload, ligament folding, foramina stenosis and other painful degenerative conditions can impose a greater limitation on mobility than that resulting from fusion of a segment, such that fixation of the diseased segment can enable better performance of the other segments. Obviously, the preoperative limitation of mobility has some subjective components, as the patient learns to avoid movements that can cause pain. When the painful condition is resolved, the movement limitation is more objective, related mainly to the mechanical restriction of the fixation. In this context, the minimally invasive approach is very important because it causes less muscular damage and preserves more motor and proprioceptive neuromuscular units.

Trunk flexibility was measured with the pelvis fixed by the physical therapist and a single fleximeter placed over L1. The use of 2 fleximeters, one placed over L1 and one over the sacrum, can better isolate the pelvis and give a more precise indication of trunk mobility. The option for the single fleximeter technique was based on papers demonstrating that mobility restriction in cases of low back pain can be related to functional restriction of hip movement, therefore a the single fleximeter technique can better estimate the overall trunk flexibility in patients' routine activities

Another issue in the methodology is the inclusion of two different segments in the sample, L4-L5 and L5-S1, each of which makes different contributions to the range of motion. For extension movements of the spine, L5S1 fusion limits movement more than L4L5. On the other hand, fusion of L4L5 involves lesser mobility in spinal flexion. ${ }^{7,8}$ Although the gain in extension represented a very small portion of the overall mobility, it was statistically significant. The mean post-operative gain in flexion had a higher value, but was not statistically significant, probably due to the effect of sample size. Nevertheless, even though the gain in flexion was not statistically significant, it was possible to demonstrate that minimally invasive fixation of L4-5 or L5-S1 does not cause loss of mobility, compared with the preoperative state, and can bring significant benefits in terms of pain and functionality.

\section{CONCLUSION}

Based on the results, it can be concluded that one-level 
minimally invasive lumbar fixation does not cause a reduction of trunk flexibility, compared to the flexibility measured in the preoperative state.

All the authors declare that there are no potential conflicts of interest regarding this article.

CONTRIBUTIONS OF THE AUTHORS: Each author made significant individual contributions to the development of the manuscript. MSS and MAS were the main contributors in the writing of the manuscript. MMS and EVA performed the surgeries. MBK and TA did the patient follow-up and compiled the clinical data. MAS evaluated the data from the statistical analysis. MSS, EVA, MBK and TA performed the bibliographic review, the revision of the manuscript, and contributed to the intellectual concept of the study.

\section{REFERENCES}

1. Tanaka N, An HS, Lim TH, Fujiwara A, Jeon CH, Haughton VM. The relationship between disc degeneration and flexibility of the lumbar spine. Spine J. 2001;1(1):47-56.

2. Haughton VM, Schmidt TA, Keele K, An HS, Lim TH. Flexibility of lumbar spinal motion segments correlated to type of tears in the annulus fibrosus. J Neurosurg. 2000;92(1 Suppl):81-6.

3. Oliveira BA, Simões MS, Abreu EV. Artrodese lombar minimamente invasiva com acesso intermuscular sem material cirúrgico especial: estudo de série de casos. Coluna/ Columna 2011;10:188-92.

4. Wiltse LL, Bateman JG, Hutchinson RH, Nelson WE. The paraspinal sacrospinalis-splitting approach to the lumbar spine. J Bone Joint Surg Am. 1968;50(5):919-26.
5. Szpalski M, Gunzburg R, Mayer M. Spine arthroplasty: a historical review. Eur Spine J. 2002;11(Suppl 2):S65-84.

6. Sullivan MS, Shoaf LD, Riddle DL. The relationship of lumbar flexion to disability in patients with low back pain. Phys Ther. 2000;80(3):240-50.

7. Miyasaka K, Ohmori K, Suzuki K, Inoue H. Radiographic analysis of lumbar motion in relation to lumbosacral stability. Investigation of moderate and maximum motion. Spine (Phila Pa 1976). 2000;25(6):732-7.

8. Auerbach JD, Jones KJ, Milby AH, Anakwenze OA, Balderston RA. Segmental contribution toward total lumbar range of motion in disc replacement and fusions: a comparison of operative and adjacent levels. Spine (Phila Pa 1976). 2009;34(23):2510-7. 